\title{
Distribution of Ha-ras alleles in patients with colorectal cancer and Crohn's disease
}

\author{
R Klingel, P Mittelstaedt, W G Dippold, K-H Meyer zum Büschenfelde
}

\begin{abstract}
The allele distribution of the Ha-ras gene on chromosome 11p was analysed by the restriction fragment length polymorphism of the enzymes Mspl/Hpall in 238 individuals. The investigation covered 116 patients with colorectal carcinoma and 122 patients with Crohn's disease, representing two patient populations with the same ethnic origin, one with a malignant and the other a benign disease of the same organ system. A total of 17 different alleles were detected belonging to the common, intermediate, and rare classes according to the original nomenclature of Ha-ras alleles. Patients with Crohn's disease showed no difference in the distribution of Ha-ras alleles when compared with expected frequencies. In patients with colorectal carcinoma, the frequency of rare alleles was significantly increased compared with the patients with Crohn's disease $\left(\chi^{2}=8 \cdot 166\right.$; Fisher's exact test $=0.005$ ) and with a reference population of 424 cancer free individuals $\left(\chi^{2}=49 \cdot 312\right.$; Fisher's exact test $\left.=0.000\right)$. Homozygosity was not detected for any rare allele. The occurrence of a rare Ha-ras allele was not linked to the location of the colorectal tumour. These results confirm the hypothesis that unique Ha-ras alleles represent an inherited factor which predisposes the development of colorectal cancer.
\end{abstract}

A polymorphism is observed at the human $\mathrm{Ha}$ ras locus on chromosome $1 \mathrm{lp}$ based on a variable nuclear tandem repeat. The restriction fragment length polymorphism (RFLP) of the Ha-ras gene arises from changes in the number of this tandemly repeated 28 bp consensus sequence located at the 3 ' flanking region of the gene. 'The polymorphic DNA segments segregate as codominant markers in a Mendelian fashion and can be used to define classes of alleles of this oncogene: common, intermediate, and rare alleles. ${ }^{2-4}$ Especially rare alleles were hypothesised to confer susceptibility to develop particular types of malignant tumours. ${ }^{3+}$ Two recent studies investigating the Ha-ras allele distribution in patients with colorectal cancer were controversial in their results, but did not use the original definition of alleles. ${ }^{56}$

A conclusive model which summarises several molecular genetic events associated with the known sequence leading from normal colonic mucosa to the hyperproliferative colonic polyps and finally to metastatic colorectal carcinoma was recently presented by Vogelstein. ${ }^{78}$ The ras oncogenes contribute to this hypothesised multi- step process of colorectal cancer development at early stages by hypomethylation and mutations when hyperproliferation has developed..$^{7-10}$ Besides this general hypothesis, there are two hereditary syndromes which predispose to colorectal cancer: familial adenomatous polyposis with the responsible gene located on chromosome $5 \mathrm{q}^{\prime \prime}$ and hereditary non-polyposis colorectal cancer, which has not as yet been linked to any genetic locus (Lynch syndromes I and II). ${ }^{12}$

Two disease entities of chronic inflammatory bowel disorders exhibit a quite different potential for the development of colorectal carcinoma. The observed number of extraintestinal cancers in both Crohn's disease and ulcerative colitis is in the range normally expected in the standard population. Ulcerative colitis represents a highly premalignant condition for colorectal carcinoma, particularly when the total colon is involved in combination with a long duration of disease. ${ }^{13}$ The risk of cancer of the colon and intestine in Crohn's disease is significantly less increased, estimated as about one third the rate found in ulcerative colitis. ${ }^{13+4}$ In general the risk of gastrointestinal cancer in chronic inflammatory bowel disease increases with the duration of the disease. ${ }^{13}$ Our aim was to analyse allele frequencies in patients with Crohn's disease and colorectal carcinoma and compare these with the known distribution of alleles.

After the initial report of Krontiris et al, ${ }^{3}$ several groups investigated the Ha-ras RFLP in a variety of malignancies. The hypothesis of a different distribution of Ha-ras alleles in patients with malignant diseases was confirmed in lung cancer, ${ }^{1516}$ acute myeloid leukaemia, ${ }^{17}$ a mixed group of Japanese cancer patients, ${ }^{18}$ and miscellaneous intracranial tumours. ${ }^{19}$ No difference was detected for myelodysplasia, ${ }^{1720}$ ovarian carcinoma, ${ }^{21}$ urothelial cancer $^{22-24}$ and Wilms' tumour..$^{2+}$ As with colonic carcinoma, results are contradictory for malignant melanoma ${ }^{2+27}$ and breast cancer. ${ }^{21}{ }^{28-30}$ It must be noted, however, that most of these studies did not use Mspi/Hpall digested DNA to define allele classes and designate exactly individual fragments according to the original nomenclature with the highest resolution. ${ }^{+}$

Because the distribution of Ha-ras alleles varies in different ethnic groups, ${ }^{2}$ we analysed two clinically well defined patient groups of homogenous ethnic origin, one with a malignant and the others a benign disease of the same organ system. We adhered strictly to the original nomenclature of alleles after digestion of DNA with $\mathrm{Mspl} / \mathrm{H}$ pall because they enable clear definition of the allele size and avoid underestimation of the total number of alleles. ${ }^{1631}$ 


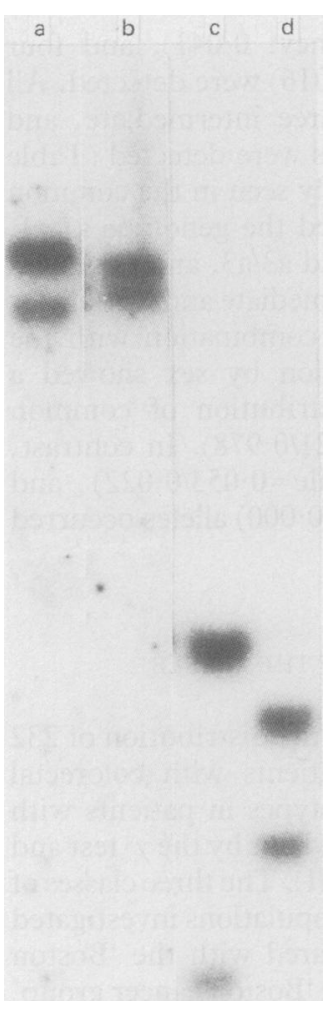

Figure 1: Resolution of $\mathrm{Ha}$ ras allelic fragments. Leukocyte DNAs representing $\mathrm{Ha}$-ras genotypes with the four common alleles: (a) BamHl digestion of genotype al $(6.9$ $\mathrm{kb}) / \mathrm{a} 4(8 \cdot 3 \mathrm{~kb}) ;(\mathrm{b}) \mathrm{BamHl}$ digestion of genotype a2 $(7 \cdot 5$ $\mathrm{kb}) / \mathrm{a} 3(8 \cdot 0 \mathrm{~kb}) ;(\mathrm{c})$ corresponding Mspl/Hpall digestion of genotype al (1000 bp)/a4 (2560 bp), and (d) corresponding Mspl/ Hpall digestion of genotype $a 2(1500 b p) / a 3(2160 b p)$.

\section{Materials and methods}

STUDY POPULATION

White blood cells were collected consecutively from 122 unrelated white patients with Crohn's disease proved by clinical examination, endoscopy, and biopsy, and with no evidence of malignancy (76 female/46 male) and 116 unrelated white patients with colorectal carcinoma ( $58 \mathrm{female} / 58 \mathrm{male}$ ). All patients were of German origin. In the group with tumours 49 $(42 \cdot 2 \%)$ had carcinomas of the rectum, 28 $(24 \cdot 1 \%)$ of the sigmoid colon, two $(1 \cdot 7 \%)$ of the descending colon, $14(12 \cdot 1 \%)$ of the transverse colon (including hepatic and splenic flexures), 18 $(15.5 \%)$ of the ascending colon (including caecum) and five $(4 \cdot 3 \%)$ patients had familial adenomatous polyposis.

\section{SOUTHERN ANALYSIS}

Leukocyte DNAs were prepared, as described previously ${ }^{32}$ and digested with $\mathrm{BamHl}$ and $\mathrm{Mspl} /$ Hpall respectively under the conditions recommended by the manufacturers. Samples $(10 \mu \mathrm{g})$ were subjected to electrophoresis (16-18 hours, constant voltage $40 \mathrm{~V}$ ) through $0.7 \%$ agarose gels for $\mathrm{BamHl}$ and $1 \%$ agarose gels for $\mathrm{Mspl} / \mathrm{Hpall}$. Southern blotting; ${ }^{32} \mathrm{P}$-labelling of DNA; and conditions for stringent hybridisation to a complete $\mathrm{c}-\mathrm{Ha}$-ras-1 probe (clone $\mathrm{pEJ}$ containing the $6.6 \mathrm{~kb} \mathrm{BamHl} \mathrm{c-Ha-ras-1} \mathrm{fragment} \mathrm{including} \mathrm{the}$ VTR region); and uncut lambda DNA were performed as described previously. ${ }^{32}$

\section{DETERMINATION OF HA-RAS GENOTYPES AND \\ ALLELE SIZES}

Alleles were designated according to the nomenclature of Krontiris. ${ }^{+}$Reference DNAs of frequent alleles a1, a2, a3, and a4 were obtained from Krontiris, Boston. Intermediate and rare alleles were measured as relative mobility by coelectrophoresis to the frequent alleles and already known fragments of similar size in adjacent tracks. Fragment sizes were then determined by linear regression analysis of the rate of migration, which is inversely proportional to the logarithm of their length in base pairs. At least two independent experiments which resulted in regression lines with $r>0.99$ for the frequent alleles were used for calculation. This procedure permits size measurements with an SD of $0.6 \%$ of the size of the individual allele. ${ }^{2}$ Hindlll and BstEll digested lambda DNAs were used as size markers. BamHl mapping was useful to indicate homozygosity or heterozygosity of the genotypes in case of some partial digestions by $\mathrm{Mspl} / \mathrm{Hpall}$. Calculation of identical fragment sizes was tested by subsequent co-electrophoresis of DNA samples.

\section{STATISTICAL ANALYSIS}

Alleles were grouped into three sets: common (expected frequency 0.07 to 0.65 ); intermediate (expected frequency 0.025 to 0.004 ); and rare alleles (expected frequency less 0.004 ) as defined by Krontiris in the largest survey (796 individuals/1592 haplotypes) of allelic distribution. ${ }^{3+}$
Comparative analysis of the genotypic or allelic distributions were performed by $2 \times 2$ contingency tables with no a priori assumption about deviations of individual alleles from the expected frequencies. Patients with colorectal carcinoma and Crohn's disease were compared with each other and with two control groups published by Krontiris, ${ }^{4}$ consisting of 424 cancer-free persons (abbreviated and referred to in the text as 'Boston cancer free group') and 372 cancer patients with a wide variety of tumours ('Boston cancer group'; the tumours were: carcinomas of head and neck $1 \%$; lung $5 \%$; breast $16 \%$; gastrointestinal tract $5 \%$ including oesophagus, stomach, pancreas, liver, colorectum; genitourinary tract $22 \%$ including kidney, bladder, prostate, testis; female reproductive tract $8 \%$ including ovary, uterus, cervix, endometrium; lymphoma $18 \%$; melanoma $4 \%$; sarcoma $2 \%$; myeloma $1 \%$; acute and chronic leukaemia $11 \%$; brain tumours $2 \%$; non-melanoma skin cancers $3 \%$; tumours of unknown primary site $2 \%) .{ }^{+}$To test differences for their significance $\chi^{2}$ test (df 1$)$ with Yates's correction for continuity and Fisher's exact test for the two tailed significance level were used, the latter because the $\chi^{2}$ test alone is not valid for the expected low range of relative frequencies of intermediate and rare alleles $\left(0.056\right.$ and 0.024 respectively $\left.^{34}\right)$.

\section{Results}

The analysis of 238 DNA samples resulted in the identification of 17 distinct types of the 32 known allelic Ha-ras haplotypes defined by the $\mathrm{Mspl} /$ Hpall restriction fragment length polymorphism $^{3+}$ (Table I) in the 116 patients with colorectal cancer and 122 with Crohn's disease. The four most frequent alleles in our patient groups proved identical to the common alleles al, a2, a3, and a4 obtained as reference probes from Krontiris (Fig 1). Linear regression analysis ( $r>0.99)$ of the mobility of $\mathrm{Mspl} / \mathrm{Hpall}$ fragments in $1 \%$ agarose gels were used to calculate intermediate and rare fragments (Fig 2). DNAs with accurately determined fragment sizes were incorporated in the further measurement of unknown fragment lengths. BamHl digested DNA samples were helpful in case of partial digestions by $\mathrm{Mspl} / \mathrm{Hpall}$ but were actually very limited in the discrimination of small size differences (Fig 3 ).

\section{GENOTYPE AND ALLELE DISTRIBUTION OF} PATIENTS WITH COLORECTAL CARCINOMA

In the 232 allelic fragments of the Ha-ras gene of 116 patients with colorectal carcinoma, 207 common (frequency 0.892 ), nine intermediate (frequency 0.039 ), and 16 rare alleles (frequency 0.069 ) were detected. All four of the known common alleles but only three of the seven intermediate alleles and eight of the 21 known rare alleles were detected (Table I). There was no significant preference of rare alleles when arranged by the anatomical site of the colorectal carcinomas (Fig 4). In the common group, 46 patients were homozygous for a1, two for a2, none for a3, and two for a4. In the intermediate group homozygosity was observed only once for 
TABLE I Ha-ras allelic frequencies in 116 patients with colorectal carcinoma and 122 patients with Crohn's disease ${ }^{\star}$

\begin{tabular}{|c|c|c|c|c|c|c|}
\hline \multirow[b]{2}{*}{ Alleles } & \multirow{2}{*}{$\begin{array}{l}\text { Size of } \\
\text { Mspl/Hpall } \\
\text { fragments }\end{array}$} & \multicolumn{2}{|c|}{$\begin{array}{l}\text { Colorectal carcinoma } \\
(n=116) \\
\text { Frequencies: }\end{array}$} & \multicolumn{2}{|c|}{$\begin{array}{l}\text { Crohn's disease } \\
(n=122) \\
\text { Frequencies: }\end{array}$} & \multirow{2}{*}{$\begin{array}{l}\text { Expected } \\
\text { relative } \\
\text { frequencies }\end{array}$} \\
\hline & & Absolute & Relative & Absolute & Relative & \\
\hline $\begin{array}{l}\text { Common: } \\
\text { a1 } \\
\text { a2 } \\
\text { a3 } \\
\text { a4 }\end{array}$ & $\begin{array}{l}1000 \\
1500 \\
2160 \\
2560\end{array}$ & $\begin{array}{r}207 \\
140 \\
24 \\
26 \\
17\end{array}$ & $\begin{array}{l}0 \cdot 892 \\
0 \cdot 608 \\
0 \cdot 103 \\
0 \cdot 108 \\
0 \cdot 073\end{array}$ & $\begin{array}{r}230 \\
161 \\
31 \\
23 \\
15\end{array}$ & $\begin{array}{l}0.943 \\
0.660 \\
0.127 \\
0.094 \\
0.062\end{array}$ & $\begin{array}{l}0.918 \\
0.612 \\
0 \cdot 121 \\
0.097 \\
0.088\end{array}$ \\
\hline $\begin{array}{l}\text { Intermediate: } \\
\text { al.2 } \\
\text { al.1 } \\
\text { a4.1 } \\
\text { a0.1 } \\
\text { al.3 } \\
\text { a1.4 } \\
\text { a5 }\end{array}$ & $\begin{array}{r}1110 \\
1060 \\
2610 \\
980 \\
1230 \\
1450 \\
2800\end{array}$ & $\begin{array}{l}2 \\
3\end{array}$ & $\begin{array}{l}0.039 \\
0.017 \\
0.009 \\
0.013\end{array}$ & $\begin{array}{r}10 \\
6 \\
2 \\
2\end{array}$ & $\begin{array}{l}0.041 \\
0.025 \\
0.008 \\
0.008\end{array}$ & $\begin{array}{l}0.056 \\
0.021 \\
0.010 \\
0.007 \\
0.005 \\
0.005 \\
0.004 \\
0.004\end{array}$ \\
\hline $\begin{array}{l}\text { Rare: } \\
\text { a3.2 } \\
\text { a2.2 } \\
\text { a2.3 } \\
\text { a2.4 } \\
\text { a3.1 } \\
\text { a3.3 } \\
\text { a3.4 } \\
\text { a1.3 } \\
\text { a2.0 } \\
\text { a3.5 } \\
\text { a4.2 } \\
\text { a0.1 } \\
\text { a0.2 } \\
\text { a1.25 } \\
\text { a2.015 } \\
\text { a2.02 } \\
\text { a2.025 } \\
\text { a2.1 } \\
\text { a2.11 } \\
\text { a2.12 } \\
\text { a5.2 }\end{array}$ & $\begin{array}{r}2280 \\
1820 \\
1880 \\
2100 \\
2220 \\
2330 \\
2410 \\
1280 \\
1560 \\
2480 \\
2710 \\
880 \\
810 \\
1180 \\
1590 \\
1650 \\
1680 \\
1710 \\
1750 \\
1790 \\
3080\end{array}$ & $\begin{array}{r}16 \\
1 \\
1\end{array}$ & $\begin{array}{l}0.069 \\
0.004 \\
0.004\end{array}$ & 4 & 0.008 & $\begin{array}{l}0 \cdot 024 \\
0 \cdot 002 \\
0 \cdot 002 \\
0 \cdot 002 \\
0 \cdot 002 \\
0 \cdot 002 \\
0 \cdot 002 \\
0 \cdot 002 \\
0 \cdot 001 \\
0 \cdot 001 \\
0 \cdot 001 \\
0 \cdot 001 \\
0 \cdot 0006 \\
0.0006 \\
0 \cdot 0006 \\
0 \cdot 0006 \\
0 \cdot 0006 \\
0.0006 \\
0.0006 \\
0.0006 \\
0.0006 \\
0.0006\end{array}$ \\
\hline
\end{tabular}

^Nomenclature and estimated frequencies of alleles represented by the Mspl/Hpall restriction fragments according to Krontiris. ${ }^{+}$
10 intermediate (frequency: $0 \cdot 041$ ), and four rare alleles (frequency 0.016 ) were detected. All four common alleles, three intermediate, and three different rare alleles were detected (Table I). Homozygosity was only seen in the common group: 53 patients showed the genotype al/al, one patient a2/a2, two had a3/a3, and none was homozygous for a4. Intermediate and rare alleles were always detected in combination with the common group. Separation by sex showed a similar frequency of distribution of common alleles (female $/$ male $=0.921 / 0.978$ ). In contrast, intermediate (female/male $=0.053 / 0.022$ ) and rare (female $/ \mathrm{male}=0 \cdot 026 / 0 \cdot 000)$ alleles occurred preferentially in women.

\section{COMPARATIVE ANALYSIS OF THE ALLELE DISTRIBUTION}

The statistical analysis of the distribution of 232 Ha-ras haplotypes in patients with colorectal carcinoma and 244 haplotypes in patients with Crohn's disease was carried out by the $\chi^{2}$ test and Fisher's exact test (Table II). The three classes of Ha-ras alleles in the two populations investigated in this study were compared with the 'Boston cancer free group' and the 'Boston cancer group' and significant differences in distribution were shown. The frequency of rare alleles in the patients with colorectal carcinoma was significantly increased. It was higher than in the patients with Crohn's disease $\left(\chi^{2}=8 \cdot 166\right.$; Fisher's exact test $=0.005)$ and the 'Boston cancer free group' $\left(\chi^{2}=49 \cdot 312\right.$; Fisher's exact test $=0 \cdot 000)$. Intermediate alleles were equally distributed in each population. Eight rare alleles were detected in 16 patients with colorectal carcinoma, whereas only three were detected in four patients with Crohn's disease. The increase in rare alleles found in colorectal carcinoma patients was at the expense of the common alleles. The decrease of common alleles was essentially identical $\left(\chi^{2}=10 \cdot 615\right.$; Fisher's exact test $=0.002$ ) to that found when the Boston cancèr group and the Boston cancer free group $0 \cdot 009$ ). In addition, the patient who was homozygous for $\mathrm{a} 0 \cdot 1$ was female.

GENOTYPE AND ALLELE DISTRIBUTION OF PATIENTS WITH CROHN'S DISEASE

In 244 allelic fragments of 122 patients with Crohn's disease, 230 common (frequency 0.943 ),

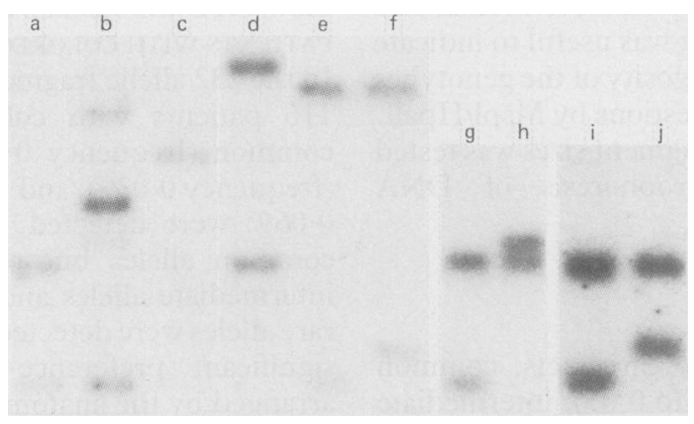

Figure 2: Examples of identified intermediate and rare $\mathrm{Ha}$-ras alleles; co-electrophoresis with common alleles a1, a2, a3, and a 4 : (a) a1/a2; (b) a $1 / a 2 \cdot 2$, weak extra bands are due to partial digestion; (c) al/a3; (d) a2/a4.1; (e) al/a4;(f) a1 $2 / a 4 ;(g)$ al/a2)(h) a2/a2.01; (i) al/a2, and (j) al 25/a2.

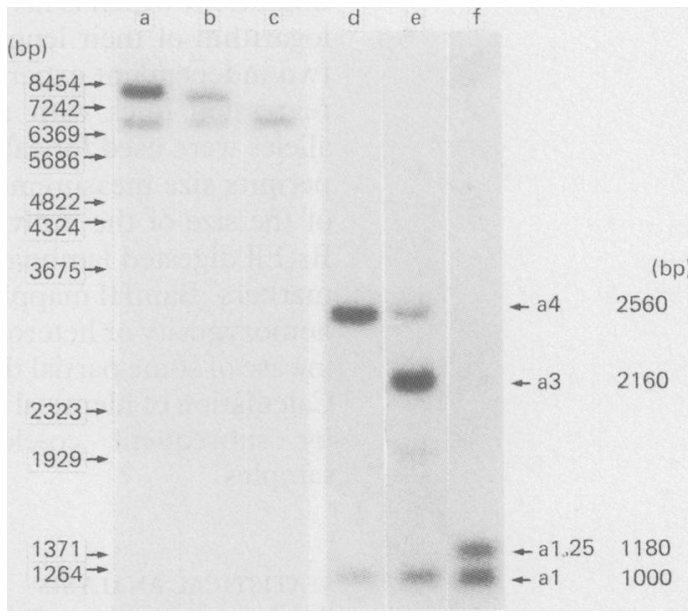

Figure 3: Comparison between $\mathrm{BamHl}(a, b, c)$ and Mspll $H$ pall $(d, e, f)$ digested DNAs (arrows on the left side of lane a represent BstEll digested lambda-DNA used as marker for the BamHl gel): genotype al/a4 (a,d); genotype alla3 $(b, e)$, partial digestion of Mspl/Hpall was confirmed by BamHl; genotype al/al $25(c, f)$, BamHl did not discriminate double band, indicating heterozygosity. 
TABLE II Statistical analysis of the distribution of Ha-ras allelic classes in patients with colorectal carcinoma (116 patients/232 haplotypes) or Crohn's disease (122 patients/244 haplotypes) compared with the Boston survey ${ }^{\star}$

\begin{tabular}{llccc}
\hline Case group & & & & \multicolumn{1}{c}{$\begin{array}{l}\text { Fisher's } \\
\text { exact test } \\
\text { (2-tail) }\end{array}$} \\
\hline Common alleles: & Comparison group & $\chi^{2}$ & p value & \\
Boston cancer group & Boston cancer free group & 25.785 & 0.000 & 0.000 \\
Colorectal carcinoma & Boston cancer free group & 10.615 & 0.001 & 0.002 \\
Crohn's disease & Boston cancer free group & 0.240 & 0.624 & 0.622 \\
Colorectal carcinoma & Boston cancer group & $0 \cdot 241$ & 0.623 & 0.725 \\
Crohn's disease & Boston cancer group & 7.624 & 0.006 & 0.005 \\
Colorectal carcinoma & Crohn's disease & 4.013 & 0.045 & 0.065 \\
Intermediate alleles: & & & & \\
Boston cancer group & Boston cancer free group & 3.361 & 0.067 & 0.083 \\
Colorectal carcinoma & Boston cancer free group & 0.295 & 0.587 & 0.722 \\
Crohn's disease & Boston cancer free group & 0.166 & 0.684 & 0.862 \\
Colorectal carcinoma & Boston cancer group & 2.714 & 0.099 & 0.177 \\
Crohn's disease & Boston cancer group & 2.410 & 0.121 & 0.128 \\
Colorectal carcinoma & Crohn's disease & 0.015 & 0.903 & 1.000 \\
Rare alleles: & & & & \\
Boston cancer group & Boston cancer free group & 38.399 & 0.000 & 0.000 \\
Colorectal carcinoma & Boston cancer free group & 49.312 & 0.000 & 0.000 \\
Crohn's disease & Boston cancer free group & 6.830 & 0.009 & 0.025 \\
Colorectal carcinoma & Boston cancer group & 1.083 & 0.298 & 0.324 \\
Crohn's disease & Boston cancer group & 5.430 & 0.020 & 0.017 \\
Colorectal carcinoma & Crohn's disease & 8.166 & 0.004 & 0.005 \\
\hline
\end{tabular}

*Calculations for Boston cancer free group (424 individuals/848 haplotypes) and Boston cancer group (372 patients/744 haplotypes) were based on the data of allele distributions in these two populations reported by Krontiris and co-workers. ${ }^{4}$ For each class of alleles, groups were compared by pairs in $2 \times 2$ contingency tables using $\chi^{2}$ test $(\mathrm{df} 1)$ and Fisher's exact test.

were compared $\left(\chi^{2}=25 \cdot 785 ;\right.$ Fisher's exact test $=0 \cdot 000)$. Although the frequency of rare Haras alleles in the Crohn's group was significantly lower than in the colorectal carcinoma group, the allele distribution was not identical to that of the Boston cancer free group. When our patients with Crohn's disease were compared with the Boston cancer group for common alleles $\left(\chi^{2}=\right.$ 7.624; Fisher's exact test $=0 \cdot 005)$ and the Boston cancer free and cancer groups for rare alleles $\left(\chi^{2}=6.830\right.$; Fisher's exact test $=0.025$ and $\chi^{2}=$ $5 \cdot 430$; Fisher's exact test $=0 \cdot 017$, respectively) significant differences were seen (Table II). These differences were not as great as those for colorectal carcinoma but were placed between Boston cancer free group and Boston cancer group (Table II).

\section{Discussion}

Three classes of alleles have been defined for the Ha-ras oncogene by a RFLP caused by a tandem repeat unit located at the 3 ' flanking region of the gene. At least 34 allelic fragments are known so far, based on the detailed nomenclature of Krontiris et al. ${ }^{3+}$ The distribution of alleles may reflect an inherited predisposition to develop certain types of malignant diseases. ${ }^{3}$ The aim of this study was to test the hypothesis that the $\mathrm{Ha}$ ras gene locus is informative for an inherited predisposition to develop colorectal cancer. To compare two well defined patient populations of identical ethnic origin, patients with colorectal carcinoma or Crohn's disease were studied. This was the first time that a distinct patient population with a benign disease of the same organ had been used as a control group. Calculation of Haras alleles adhered to the definitions of $\mathrm{Mspl} /$ Hpall restriction fragments in the largest comparable survey of subjects. ${ }^{3+}$

Two previous studies investigating colorectal carcinoma are not comparable because of the methodology used. In one study, 62 patients who were categorised into only eight different Taql defined alleles did not exhibit a cancer related allele distribution. ${ }^{5}$ In contrast, a significant increase in the frequency of two alleles was shown in 46 patients classified by nine Avall defined allelic fragments. ${ }^{6}$ The conflicting results concerning several other tumour types are the result of differences in methodology which lead to an underestimation of the total number of alleles. Furthermore, site polymorphisms for Avall in the frequent allele a 2 and for Taql in a4 exist. ${ }^{17}$ The results indicate that each tumour type must be examined separately for an association with a group of Ha-ras alleles; these need not be the rare alleles. In lung cancer patients in the United Kingdom, a difference in distribution of one of the common alleles was observed between small cell lung cancer and non-small cell lung cancer. ${ }^{15}$ But this study also used a different designation of alleles after digestion of DNA with Pvull.

By comparing the distribution of Ha-ras alleles of patients with Crohn's disease and those with colorectal carcinoma, we could confirm the hypothesis that colorectal carcinoma belongs to the group of malignant tumours associated with rare Ha-ras alleles. ${ }^{3}$ A statistically significant greater frequency of rare Ha-ras alleles occurred in patients with colorectal cancer than in Crohn's disease patients. This difference was also significant when both groups were compared with two control populations analysed by identical methods: 424 persons without a malignant disease (Boston cancer free group) and 372 patients with a wide variety of malignant diseases (Boston cancer group). ${ }^{4}$ Like the colorectal

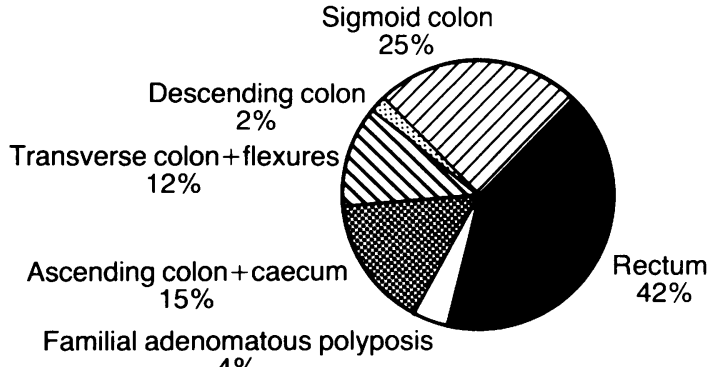

$4 \%$

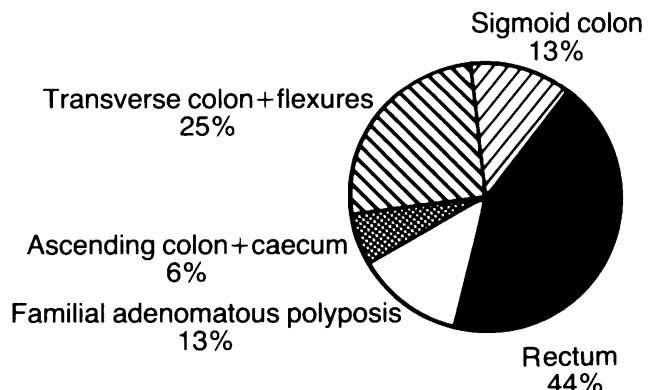

Figure 4: Anatomical sites of tumours of the 116 patients with colorectal cancer compared with the distribution of detected rare alleles in these sites. No significant preference could be detected. 
cancer patients, the Boston cancer group showed a significantly increased frequency of rare alleles. Alleles of the rare group were not found exclusively in the cancer patients. Statistical analysis placed the patients with Crohn's disease between the Boston cancer free group and colorectal carcinoma patients. The finding of a different distribution of the Ha-ras genotype in colorectal carcinoma and in Crohn's disease must be considered in parallel with the observation that ulcerative colitis is a highly premalignant risk factor while Crohn's disease is not. ${ }^{13}$ But the incidence of colorectal cancer in patients with Crohn's disease is not identical to that of the general population. ${ }^{1314}$ Our results could mean that the malignant potential of Crohn's disease is reflected by an increased rate of rare Ha-ras alleles which were correlated to colorectal carcinoma.

The observation that the allele distribution showed certain differences in the two disease populations when the sexes were separated should not lead to speculation but must be noted. Intermediate alleles occurred predominantly in women in both groups and the rare allele group consisted exclusively of women with Crohn's disease. In 100 Japanese women with breast carcinoma, there was no significant difference in allele distribution compared with the normal population..$^{18}$

The relevance of the inheritance of different Ha-ras alleles with regard to susceptibility to other types of cancer has to be elucidated. The functional explanation could be found in the enhancer activity of the repetitive sequence element $3^{\prime}$ of the human Ha-ras gene. Based on the polymorphism, the activity of this enhancer is variable within the human population. ${ }^{33}{ }^{34}$ In addition, allele specific methylation patterns have been observed. ${ }^{35}{ }^{36}$ Within the scope of the multistep model of colorectal tumorigenesis, hypomethylation and mutations of the ras oncogenes occur in the early neoplastic stages. ${ }^{78}$ This could be part of a mechanism whereby individual Ha-ras alleles promote colorectal cancer. Only indirect evidence exists for an influence of Ha-ras alleles over the expression of the gene. In lung squamous cell carcinomas, Krontiris et al recently showed an increased frequency of rare Ha-ras alleles, ${ }^{16}$ and these tumours frequently exhibit raised Ha-ras expression. ${ }^{37}$ Increased expression of the Ha-ras gene was also shown for colorectal carcinoma ${ }^{38} 39$ and has to be considered as an early phenomenon of colorectal tumorigenesis. ${ }^{39}$

The putative influence of Ha-ras alleles on cancer development must be based on independent alleles. Homozygosity was not seen for any rare allele and no significant differences between colorectal cancer and Crohn's disease patients were detected at the level of the complete Ha-ras genotype. The occurrence of an individual Ha-ras allele cannot be considered a general predisposition to malignancy - for example, to identify affected people - but could help define subgroups of patients with a special tumour, which could be important in determining the best treatment strategies. Other benign diseases could also be tested for a malignant potential, in cases where the malignant tumour of the involved organ system shows a distribution of Ha-ras alleles that is different to that found normally. Attempts to correlate the Ha-ras allele distribution to clinical or biological characteristics of a particular type of tumour or disease need larger surveys to resolve these issues.

We wish to thank Dr Wellek, Department of Medical Statistics, University of Mainz, for help in the statistical analysis. This work was supported by a grant from the DFG K1 578/2-1.

1 Capon DJ, Chen EY, Levinson AD, Seeburg PH, Goedde DV. Complete nucleotide sequences of the T24 huma bladder carcinoma oncogene and its normal homologue. Nature 1983; 302: 33-7.

2 Baird M, Balazs I, Giusti A, et al. Allele frequency distribution of two highly polymorphic DNA sequences in three ethnic groups and its application to the determination of paternity. Aroups and its application to the deter

3 Krontiris TG DiMartino NA, Colb $M$, Parkinson DR Unique allelic restriction fragments of the human Ha-ras locus in leukocyte and tumour DNAs of cancer patients Nature 1985; 313: 369-74.

4 Krontiris TG, DiMartino NA, Mitcheson HD, Lonergan JA, Begg C, Parkinson DR. Human hypervariable sequences in risk assessment: rare Ha-ras alleles in cancer patients. Environ Health Perspect 1987; 76: 147-53.

5 Ceccherini-Nelli L, De Re V, Viel A, Molaro G, Zilli L, Clemente $\mathrm{C}$, et al. Ha-ras-1 restriction fragment length polymorphism and susceptibility to colon adenocarcinoma. Brf Cancer 1987; 56: $1-5$

6 Wyllie FS, Wynford-Thomas V, Lemoine NR, Williams GT Williams ED, Wynford-Thomas D. Ha-ras restriction fragment length polymorphisms in colorectal cancer. $\mathrm{Br} F$ ment length polymorp

Cancer 1988; 57: 135-8.
Stanbridge EJ. Identifying tumor suppressor genes in human colorectal cancer. Science 1990; 247: 12-3.

8 Fearon ER, Vogelstein B. A genetic model for colorecta tumorigenesis. Cell 1990; 61: 759-67.

9 Feinberg AP, Vogelstein B. Hypomethylation of ras oncogenes in primary human cancers. Biochem Biophys Res Comm 1983; 111: 47-54.

10 Vogelstein B, Fearon ER, Hamilton SR, et al. Genetic alterations during colorectal tumor development. $N$ Engl f Med 1988; 319: 525-32.

11 Bodmer WF, Bailey CJ, Bodmer J, et al. Localization of the gene for familial adenomatous polyposis on chromosome 5 Nature 1987; 328: 614-6.

12 Lynch PM, Lynch HT, Lynch JF. Hereditary nonpolyposis colon cancer: epidemiologic and clinical-genetic features. In: Lynch PM, Lynch HT, eds. Colon cancer genetics. New York: Van Nostrand Reinhold, 1985: 52-98.

13 Dobbins WO. Dysplasia and malignancy in inflammatory bowel disease. Ann Rev Med 1984; 35: 33-48.

14 Greenstein AJ, Sachar DB, Smith H, Janowitz HD, Aufses AH. A comparison of cancer risk in Crohn's disease and ulcerative colitis. Cancer 1981; 48: 2742-5.

15 Heighway J, Thatcher N, Cerny T, Hasleton PS. Genetic predisposition to human lung cancer. Brf Cancer 1986; 53 : 453-7.

16 Sugimura H, Caporaso NE, Modali RV, et al. Association of rare alleles of the Harvey ras protooncogene locus with lung cancer. Cancer Res 1990; 50: 1857-62.

17 Carter G, Worwood M, Jacobs A. The Ha-ras polymorphism in myelodysplasia and acute myeloid leukaemia. Leukemia Research 1988; 12: 385-91.

18 Honda $\mathrm{K}$, Ishizaki $\mathrm{K}$, Ikenaga $M$, Toguchida J, Tanaka $\mathrm{K}$, Ozawa K. Increased frequency of specific alleles of the c-Haras gene in Japanese cancer patients. Hum Genet 1988; 79: 297-300.

19 Diedrich U, Eckermann O, Schmidtke J. Rare Ha-ras and c-mos alleles in patients with intracranial tumors. Neurology c-mos alleles in

20 Thein SL, Oscier DG, Flint J, Wainscoat JS. Ha-ras hypervariable alleles in myelodysplasia. Nature 1986; 321:84-5.

21 Corell B, Zoll B. Comparison between the allelic frequency distribution of the Ha-rasl locus in normal individuals and patients with lymphoma, breast and ovarian cancer. Hum Genet 1988; 79: 255-9.

22 Ishikawa J, Maeda S, Kamidono S, Sugiyama T. Restriction fragment length polymorphism and activation of c-Ha-ras gene in urothelial cancer. Anticancer Res 1988; 8: 915-24.

23 Ishikawa J, Maeda S, Takahashi R, Kamidono S, Sugiyama T. Lack of correlation between rare Ha-ras alleles and urothelial cancer in Japan. Int $\mathcal{f}$ Cancer 1987; 40: 474-8.

24 Hayward NK, Keegan R, Nancarrow DJ, et al. C-Ha-rasalleles in bladder cancer, Wilms' tumour and malignant melanoma. Hum Genet 1988; 78: 115-20.

25 Gerhard DS, Dracopoli NC, Bale SJ, et al. Evidence against Ha-ras-1 involvement in sporadic and familial melanoma. Nature 1987; 325: 73-5.

26 Radice P, Pierotti MA, Borrello MG, Illeni MT, Rovini D, Porta GD. HRAS1 proto-oncogene polymorphisms in human malignant melanoma: Taql defined alleles significantly associated with the disease. Oncogene 1987; 2: 91-5.

27 Sutherland C, Shaw HM, Roberts C, et al. Harvey-ras oncogene restriction fragment alleles in familial melanoma kindreds. Br f Cancer 1986; 54: 787-90.

28 Barkardottir RB, Johannsson OT, Arason A, Gudnason V, Egilsson V. Polymorphism of the c-Ha-ras-1 proto-oncogene 
in sporadic and familial breast cancer. Int $\mathcal{F}$ Cancer 1989; 44: 251-5.

29 Lidereau R, Escot C, Theillet $\mathrm{C}$, et al. High frequency of rare alleles of the human c-Ha-ras-1 proto-oncogene in breast cancer patients. $\mathcal{F N C l} 1986 ; 77: 697-701$.

30 White GRM, Heighway J, Williams GT, Scott D. Constitutional frequency of rare alleles of c-Ha-ras in breast cancer

31 Krontiris TG, DiMartino NA, Colb $M$, Mitcheson HD, Parkinson DR. Human restriction fragment length polymorphisms and cancer risk assessment. $\mathcal{F}$ Cell Biochem 1986; 30: 319-29.

32 Klingel R, Mincheva A, Gissmann L, Dippold W, Meyer zum Büschenfelde $\mathrm{K}-\mathrm{H}$, zur Hausen $\mathrm{H}$. An amplification unit in human melanoma cells showing partial homology with sequences of human papillomavirus type 9 and nuclear antigen 1 of the Epstein-Barr virus. Cancer Res 1987; 47: 4485-92.

33 Cohen JB, Walter MV, Levinson AD. A repetitive sequence element $3^{\prime}$ of the human C-Ha-ras 1 gene has enhancer activity. F Cell Physiol 1987; Suppl 5: 75-81.
34 Spandidos DA, Holmes L. Transcriptional enhancer activity in the variable tandem repeat DNA sequence downstream of the human Ha-rasl gene. FEBS Lett 1987; 218: 41-6.

35 Bedford MT, van Helden PD. Allele specific methylation of the H-ras gene. $\mathcal{F}$ Cancer Res Clin Oncol 1990; 116 (suppl): 16.

36 Chandler LA, Ghazi H, Jones PA, Boukamp P, Fusenig NE. Allele-specific methylation of the human c-Ha-ras-l gene. Cell 1987; 50: 711-7.

37 Kurzrock R, Gallick GE, Gutterman JU. Differential expression of $\mathrm{p} 21$ ras gene products among histological subtypes of fresh primary human lung tumors. Cancer Res 1986; 46: $1530-4$.

38 Gallick GE, Kurzrock R, Kloetzer WS, Arlinghaus RB, Gutterman JU. Expression of p21 ras in fresh primary and metastatic human colorectal tumors. Proc Natl Acad Sci USA 1985; 82: 1795-9.

39 Jansson DS, Radosevich JA, Carney WP, Rosen ST, Schlom J, Staren ED, et al. An immunohistochemical analysis of ras oncogene expression in epithelial neoplasms of the colon. Cancer 1990; 65: 1329-37. 